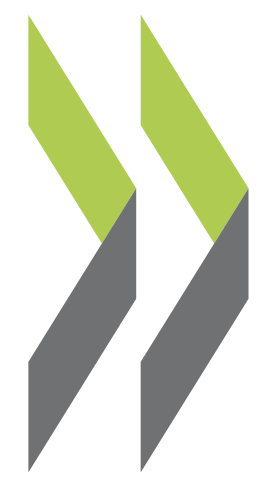

OECD Economics Department Working Papers No. 1233

Skills and labour market

Margherita Bussi, performance in Sweden Jon Pareliussen 


\section{Unclassified}

ECO/WKP(2015)51

Organisation de Coopération et de Développement Économiques

Organisation for Economic Co-operation and Development

28-May-2015

ECONOMICS DEPARTMENT

English - Or. English

SKILLS AND LABOUR MARKET PERFORMANCE IN SWEDEN

ECONOMICS DEPARTMENT WORKING PAPERS No. 1233

By Margherita Bussi and Jon Kristian Pareliussen

OECD Working Papers should not be reported as representing the official views of the OECD or of its member countries. The opinions expressed and arguments employed are those of the author(s).

Authorised for publication by Robert Ford, Deputy Director, Country Studies Branch, Economics Department.

All OECD Economics Department Working Papers are available at www.oecd.org/eco/workingpapers

JT03377296

Complete document available on OLIS in its original format

This document and any map included herein are without prejudice to the status of or sovereignty over any territory, to the delimitation of international frontiers and boundaries and to the name of any territory, city or area. 
OECD Working Papers should not be reported as representing the official views of the OECD or of its member countries. The opinions expressed and arguments employed are those of the author(s).

Working Papers describe preliminary results or research in progress by the author(s) and are published to stimulate discussion on a broad range of issues on which the OECD works.

Comments on Working Papers are welcomed, and may be sent to the Economics Department, OECD, 2 rue André-Pascal, 75775 Paris Cedex 16, France, or by e-mail to econ.contact@oecd.org.

This document and any map included herein are without prejudice to the status of or sovereignty over any territory, to the delimitation of international frontiers and boundaries and to the name of any territory, city or area.

The statistical data for Israel are supplied by and under the responsibility of the relevant Israeli authorities. The use of such data by the OECD is without prejudice to the status of the Golan Heights, East Jerusalem and Israeli settlements in the West Bank under the terms of international law.

\section{(C) OECD (2015)}

You can copy, download or print OECD content for your own use, and you can include excerpts from OECD publications, databases and multimedia products in your own documents, presentations, blogs, websites and teaching materials, provided that suitable acknowledgment of OECD as source and copyright owner is given. All requests for commercial use and translation rights should be submitted to rights@oecd.org 


\section{ABSTRACT/RÉSUMÉ \\ Skills and labour market performance in Sweden}

Both educational attainment and skills, as measured in the OECD Survey of Adult Skills (PIAAC), are high in Sweden. They are not perfect substitutes, but both are to some degree necessary for successfully integrating in the Swedish labour market. This paper describes the distribution of proficiency in literacy in the population and explores its determinants, and uncovers a strong relationship between literacy and the likelihood of being employed. The relationship between proficiency in literacy and the likelihood of participating in adult education is also explored. Lower employment prospects for immigrants are well explained by lower literacy proficiency, lower education and less favourable socio-economic backgrounds.

This Working Paper relates to the 2015 OECD Economic Survey of Sweden www.oecd.org/eco/surveys/economic-survey-sweden.htm

JEL classification: J01, J15, J21, J24, J71.

Keywords: PIAAC, adult skills, employment, education, immigration, discrimination.

\section{Compétences et performance du marché du travail en Suède}

Tant le niveau de qualification que celui de compétences, telles que mesuré dans l'évaluation des compétences des adultes (PIAAC), sont élevés en Suède. Ils ne sont pas de parfaits substituts, mais les deux sont dans une certaine mesure nécessaires à l'intégration avec succès sur le marché du travail suédois. Ce document décrit la distribution de la population en termes de niveau de compréhension de l'écrit et explore ses déterminants, et met en évidence une solide relation entre le niveau de compréhension de l'écrit et la probabilité d'être employé. La relation entre niveau de compréhension de l'écrit et la probabilité de participer à la formation continue est également explorée. Les moindres perspectives d'emploi des immigrants sont bien expliquées par un niveau inférieur de compréhension de l'écrit, un faible niveau de qualification et des milieux socio-économiques moins favorables.

Ce document de travail se rapporte à l'Étude économique de l'OCDE de la Suède, 2015. www.oecd.org/fr/eco/etudes/etude-economique-suede.htm

JEL classification: J01, J15, J21, J24, J71.

Mots clés : PIAAC, compétences des adultes, emploi, éducation, immigration, discrimination. 


\section{TABLE OF CONTENTS}

SKILLS AND LABOUR MARKET PERFORMANCE IN SWEDEN ….................................................

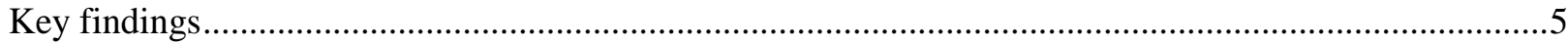

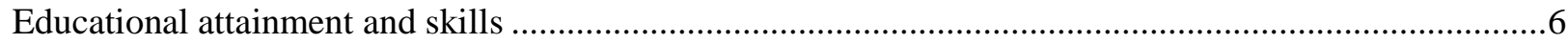

The skills of the younger cohorts .....................................................................................................

How does the socio-economic background affect literacy scores? ........................................................10

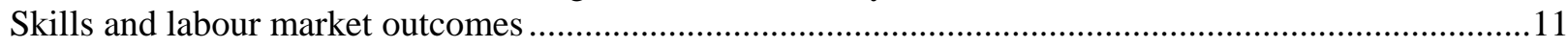

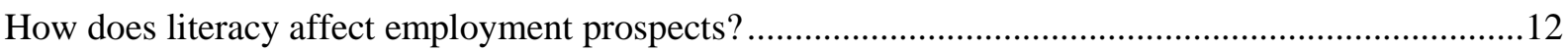

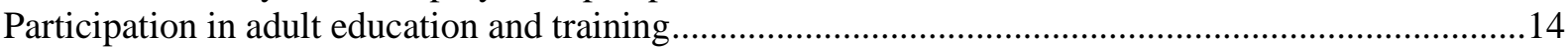

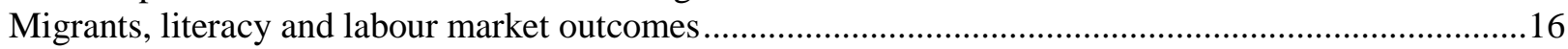

Skills improve markedly with the time spent in the country ............................................................18

How does immigrants' socio-economic background affect their literacy scores? ...............................19

How does literacy affect immigrants’ employment prospects? ........................................................21

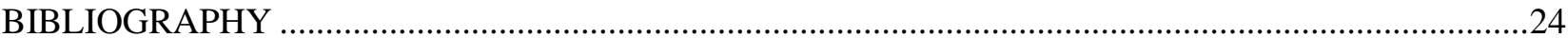

\section{Tables}

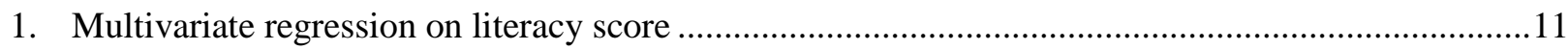

2. Logit regression on the probability of being employed ............................................................13

3. Logit regression on the likelihood of participating in formal and non-formal adult education ..........16

4. Multivariate regressions on literacy proficiency among foreign-born adults ....................................20

5. Logit regression on the probability of being employed for foreign-born adults ...............................22

\section{Figures}

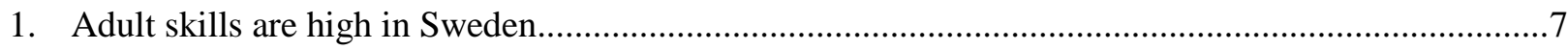

2. Countries with low scores in PISA also score low in PIAAC ..........................................................

3. Literacy proficiency differs widely by educational attainment and origin........................................

4. Literacy proficiency and labour market position ..............................................................................12

5. Literacy proficiency by educational attainment and region of birth .............................................18

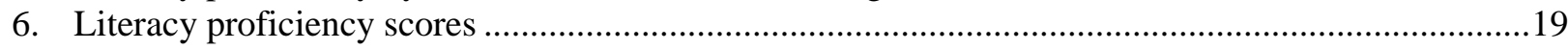

\section{Boxes}

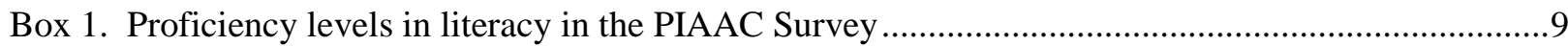

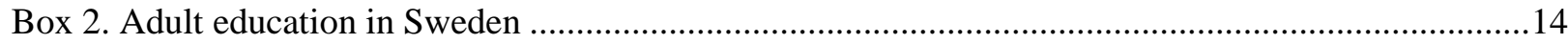


ECO/WKP(2015)51

\title{
SKILLS AND LABOUR MARKET PERFORMANCE IN SWEDEN
}

\author{
By Margherita Bussi and Jon Kristian Pareliussen ${ }^{1}$
}

Both educational attainment and skills, as measured in the OECD Survey of Adult Skills (PIAAC), are high in Sweden. The country is increasingly specialised in technology-intensive and high value-added activities, which require a strong contribution from human capital (OECD, forthcoming). Hence, maintaining a high level of skills is essential to bolster the competitiveness of the economy. The relative decline in skills among the younger cohorts suggested by the most recent OECD Programme for International Student Assessment (PISA) and PIAAC surveys may threaten Sweden's position in the global economy over the long run. Ensuring that the most disadvantaged groups, including immigrants, can build the necessary skills to successfully participate in the labour market is also essential to contain the rise in income inequality. While the employment rate for medium- and high-skilled individuals is high, the lowskilled and those with an immigrant background have difficulties finding jobs. The challenge of enhancing job opportunities for these groups is all the greater as the specialisation of the economy skews the demand for labour towards high-skilled workers while high immigration rates boost low-skilled labour supply. Against this background, this paper describes the distribution of proficiency in literacy in the population and explores its determinants. While skills in numeracy and problem solving in technology-rich environments are also assessed in PIAAC, this paper focusses on literacy, as the most universal requirement in the labour market and a particular obstacle for many immigrants with a foreign native language. Furthermore, proficiency levels in different skills tend to be correlated. The paper also examines the relationship between literacy and the likelihood of being employed. As lifelong education and training can play a decisive role in raising skills and employment opportunities, the relationship between proficiency in literacy and the likelihood of participating in adult education is explored. The analysis is carried out for the whole population and for immigrants, as the latter face particular difficulties gaining employment.

\section{Key findings}

- $\quad$ Relying on technology-intensive and high value-added production, Sweden is in need of a highly skilled workforce. A high level of tertiary educational attainment has already been achieved among the younger cohorts. Nonetheless, the PIAAC survey shows that educational attainment does not always correspond to a high level of basic skills like literacy. The fall in the results in the PISA Survey is consistent with lower adult skills for the youngest PIAAC cohorts.

- High formal qualifications and high skills proficiency are not perfect substitutes, but both are to some degree necessary for successfully integrating in the Swedish labour market, where the low skilled and low qualified end up without employment more often than on average in countries participating in PIAAC. Adult education and training can help the low-skilled, but even though Sweden outperforms the average country in PIAAC, the low-skilled are less likely to participate in such training than the high-skilled.

1. Margherita Bussi is a researcher at the European Trade Union Institute (ETUI) in Brussels, and Jon Kristian Pareliussen is Economist in the Economics Department of the OECD. This paper was originally produced as a background document for the 2015 OECD Economic Survey of Sweden, published in March 2015 (OECD, 2015a) under the authority of the Economic and Development Review Committee (EDRC). The authors would like to thank the Swedish authorities, as well as OECD colleagues; Christophe André and Vincent Koen (Economics Department), William Thorn (Education Directorate), Emily Farchy, Kristoffer Lundberg and Guillermo Montt (Employment, Labour and Social Affairs Directorate) for helpful comments and suggestions. Thomas Chalaux provided statistical research, and Mercedes Burgos and Nadine Dufour secretarial assistance. 
- $\quad$ Sweden has the biggest gap in proficiency in literacy between employed and unemployed or inactive in the OECD. When controlling for a set of socio-demographic variables, a onestandard-deviation increase in literacy proficiency is associated with $85 \%$ higher odds of being employed. Holding at most lower secondary education implies $51 \%$ lower odds of being employed compared to individuals holding an upper secondary qualification.

- In 2013, 16\% of Sweden's population was born abroad. The migrant population is set to increase in the coming years, with a substantial share of immigrants being asylum seekers and refugees who are harder to integrate than work migrants. Foreign-born and foreign-speaker adults have lower literacy proficiency compared to native-born and native-speaker adults. Those who speak a European language have higher literacy scores than the average immigrant, while Arabic and Asian language speakers have lower scores. Similar results obtain when controlling for region of origin, with Europeans scoring higher than the others. Improvement in the literacy scores of migrants who have stayed over five years is higher than on average in countries participating in PIAAC.

- Foreign-born adults' likelihood of being employed is well predicted by literacy proficiency and educational attainment. However, women are less likely to work than men when controlling for skills and other background variables.

The paper is structured in three parts. The first describes the distribution and determinants of skills in particular literacy proficiency - with a special focus on the younger cohorts. The second investigates the correlation of literacy proficiency with employment prospects, as well as with the likelihood of participating in adult education and training. The third examines the contribution of socio-economic characteristics to variations in literacy scores among immigrants and the impact of these scores on the probability of being employed.

\section{Educational attainment and skills}

In Sweden, the increasing demand for high skills in the economy and an overall expansion of the higher education system - in terms of participation and numbers of higher education institutions (Thunborg and Bron, 2012) - have pushed up educational attainment, particularly among the younger cohorts. The share of young adults (25-34) with tertiary education has increased by 12 percentage points since the turn of the millennium and $45 \%$ of young adults obtained a tertiary education degree in 2013, compared with a European average of $36 \%$. The share of young people holding a tertiary degree was 16 percentage points higher than for older people (55-64), again slightly above the European average.

The share of young adults with low educational attainment (lower secondary or less) remained stable at 13\% between 2000 and 2013. A slightly different picture is found in Denmark and Finland. In Denmark, there are clear signs of polarisation of educational attainment across youth with an increasing share of both tertiary graduates and low achievers, and a declining share of middle-skilled. In Finland the share of middle skilled has increased (Eurostat, 2014).

Looking at formal qualifications gives only a partial picture of the skills of the workforce, as formal qualifications can correspond to very different levels of specific and general skills. PIAAC measures three cognitive skills of adults (16-65), namely literacy, numeracy and problem solving in technology-rich environments, complementing data on formal qualifications. Sweden ranks above the OECD average on all three key competences measured by PIAAC (Figure 1). In literacy, Sweden ranks just below the top performers, with a performance similar to Australia and Norway. The mean score in numeracy in Sweden is similar to the one in Denmark, the Netherlands, Norway and Flanders (Belgium) and significantly above the OECD average (OECD, 2013a). 
Figure 1. Adult skills are high in Sweden Scores in the OECD Survey of Adult Skills ${ }^{1}$

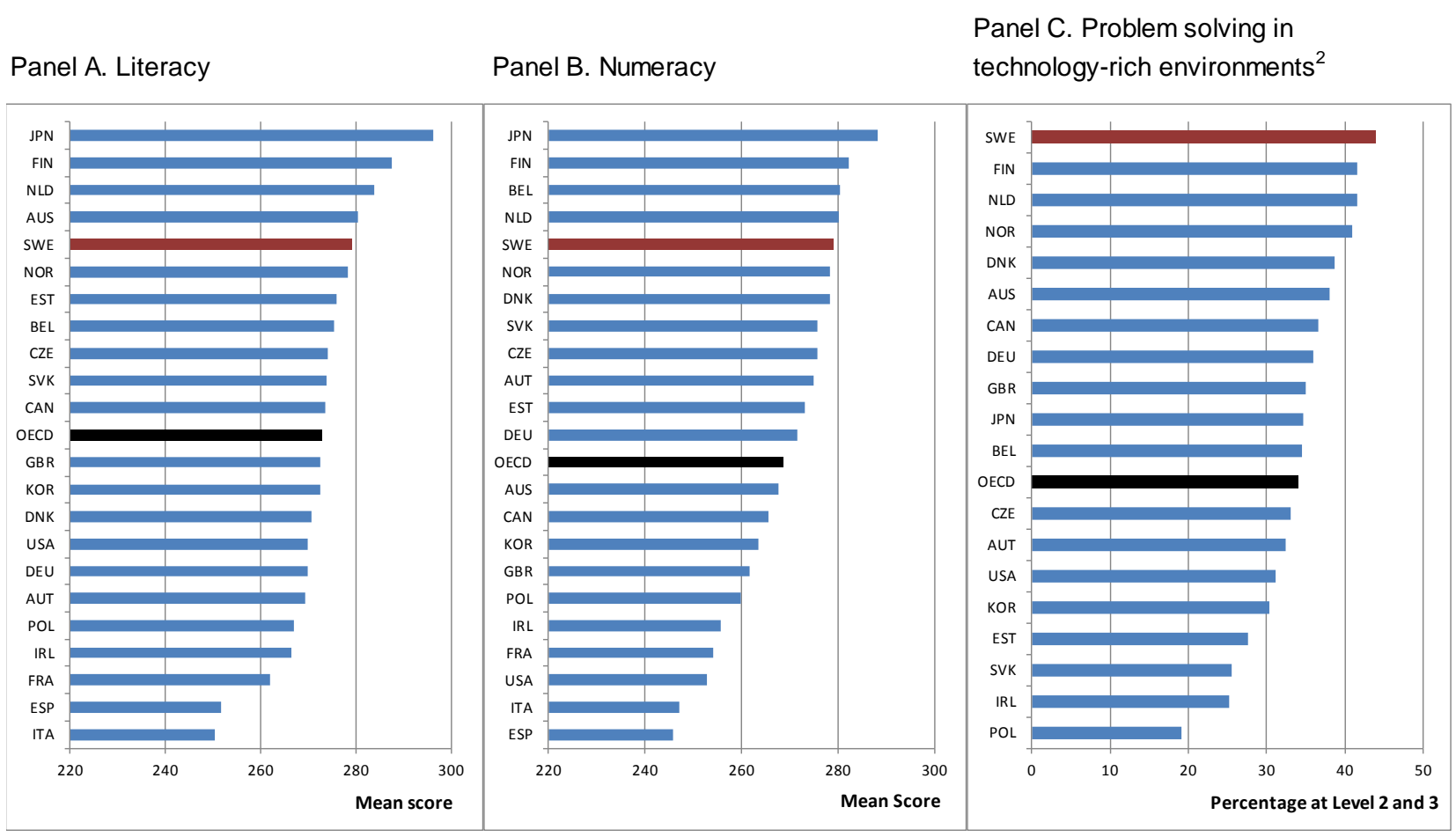

1. BEL refers to the region of Flanders. GBR refers to England and Northern Ireland.

2. Levels 2 and 3 are the highest proficiency levels on a four-level scale from below 1 to 3 . Percentages of the population with the highest attainments are shown, since scores are highly dependent on the proportion of adults who completed the assessment, and this varies across countries. France, Italy and Spain did not field the problem solving in technology-rich environments assessment.

Source: Survey of Adult Skills (2012).

Sweden has the largest share of top performing adults on problem solving in technology-rich environments. A significant share (62\%) of Swedish young people (16 to 24) reached a proficiency corresponding to Level 2 or above, while only a small minority (5\%) was below Level 1. Sweden also presents a proportion of adults from disadvantaged backgrounds - defined as adults with neither parent having attained upper secondary education - reaching Level 2 and 3 of proficiency in problem solving (25\%) above the PIAAC average of 16\% (OECD, 2013a).

\section{The skills of the younger cohorts}

By combining results from PIAAC and PISA, it is possible to follow skills developments in the younger cohorts. In Sweden the mean score in reading has been decreasing continuously between the first PISA assessment in 2000 and the most recent vintages. Across the OECD countries which participated in both surveys, those that performed well (poorly) in PISA generally also display high (low) scores in literacy for the corresponding cohorts in PIAAC. Moreover, while a number of countries have had aboveaverage results in PISA and below-average scores in PIAAC, none have scored below-average in PISA and significantly above-average in PIAAC (Figure 2). This suggests that it is very difficult to catch up from low performance at an early stage. Hence, it is likely that low literacy performance among 15-year olds in Sweden will lead to a decreasing performance among adults in the future. 
Figure 2. Countries with low scores in PISA also score low in PIAAC Comparing mean reading scores in PISA with literacy scores in PIAAC for the corresponding cohorts ${ }^{1}$

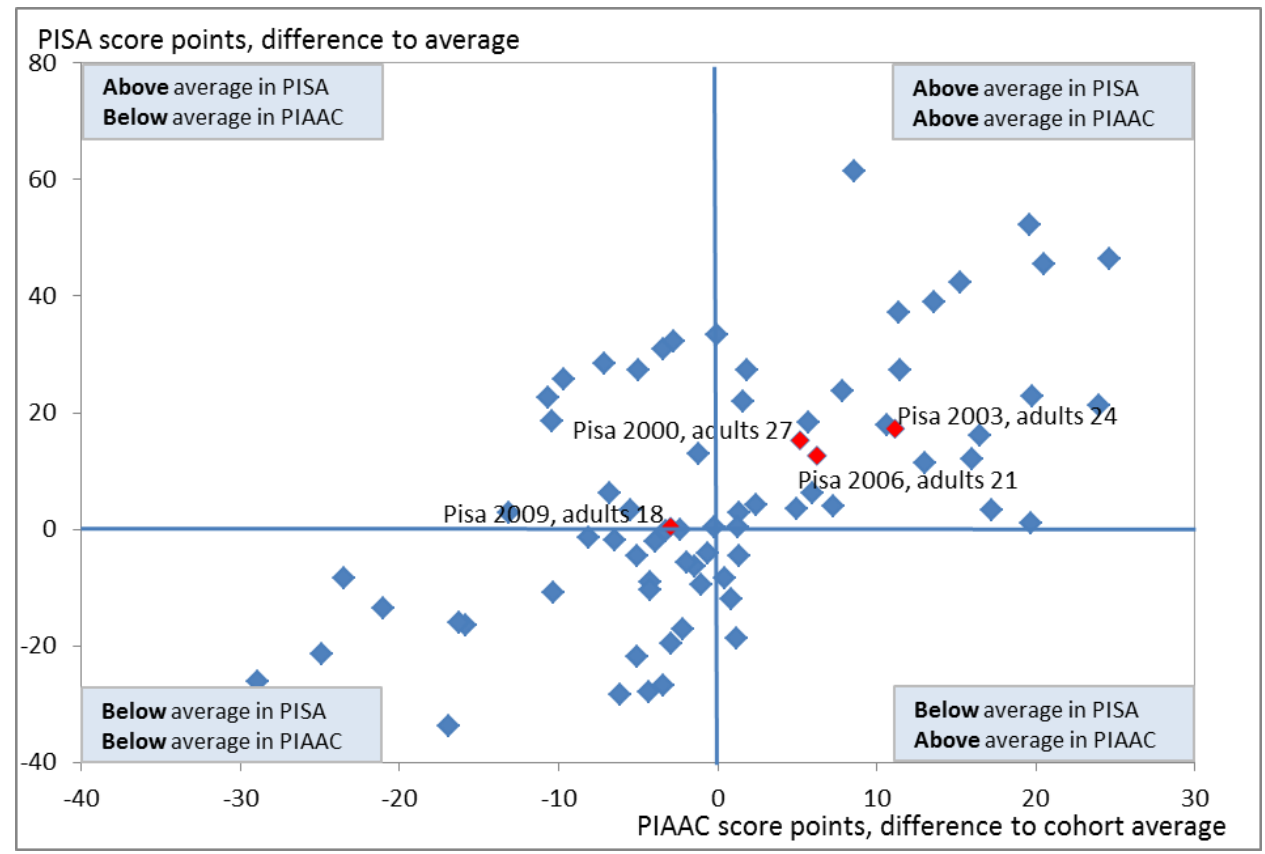

1. Sweden is displayed in red. A three-year band is used in the Survey of Adult Skills to increase size and reliability of estimates, i.e. the group "adults 24" consists of the age groups from 23 to 25 . The mix of countries contributing to the average in PISA and the Survey of Adult Skills differs, which may contribute to differences in countries' average scores relative to the overall averages in either study.

Source: Survey of Adult Skills (2012) and OECD, PISA 2009 Database, Table A5.6 (L).

Skills vary widely with educational attainment. Young people following vocational upper secondary programmes have lower literacy proficiency (See box 1 for definition of levels) than young people in general programmes, while the skill level in tertiary vocational education is on par with tertiary academic education. However, differences in mean scores between groups having followed general and vocational education need to be interpreted carefully because PIAAC tests general literacy skills, but fails to grasp work-related and specific skills. Skills also vary considerably between individuals with similar education attainment. The largest differences between the $25^{\text {th }}$ and $75^{\text {th }}$ percentiles are found among those with a degree from compulsory school or lower and those who have a tertiary academic degree (Figure 3 , Panel A).

Sweden has a high share of students with an immigrant background (15\% of 15-year-olds). The PISA 2012 survey shows that young students with an immigrant background scored 40 points lower in mathematics, even when controlling for socio-economic status (OECD, 2013b). Although the gap in proficiency in mathematics between native and immigrant students (both first and second generation) has been reduced since the PISA 2003 results, the improvement is slower (-6 points) than the OECD average (-10 points) (OECD, 2012a). The difference in mean score for literacy proficiency between native and foreign-born with the same educational attainment is large in the younger cohorts of PIAAC (Figure 3, Panel B). The gap between the 25th and 75th percentiles is also wider for foreign-born than for native young adults. 
Figure 3. Literacy proficiency differs widely by educational attainment and origin ${ }^{1}$

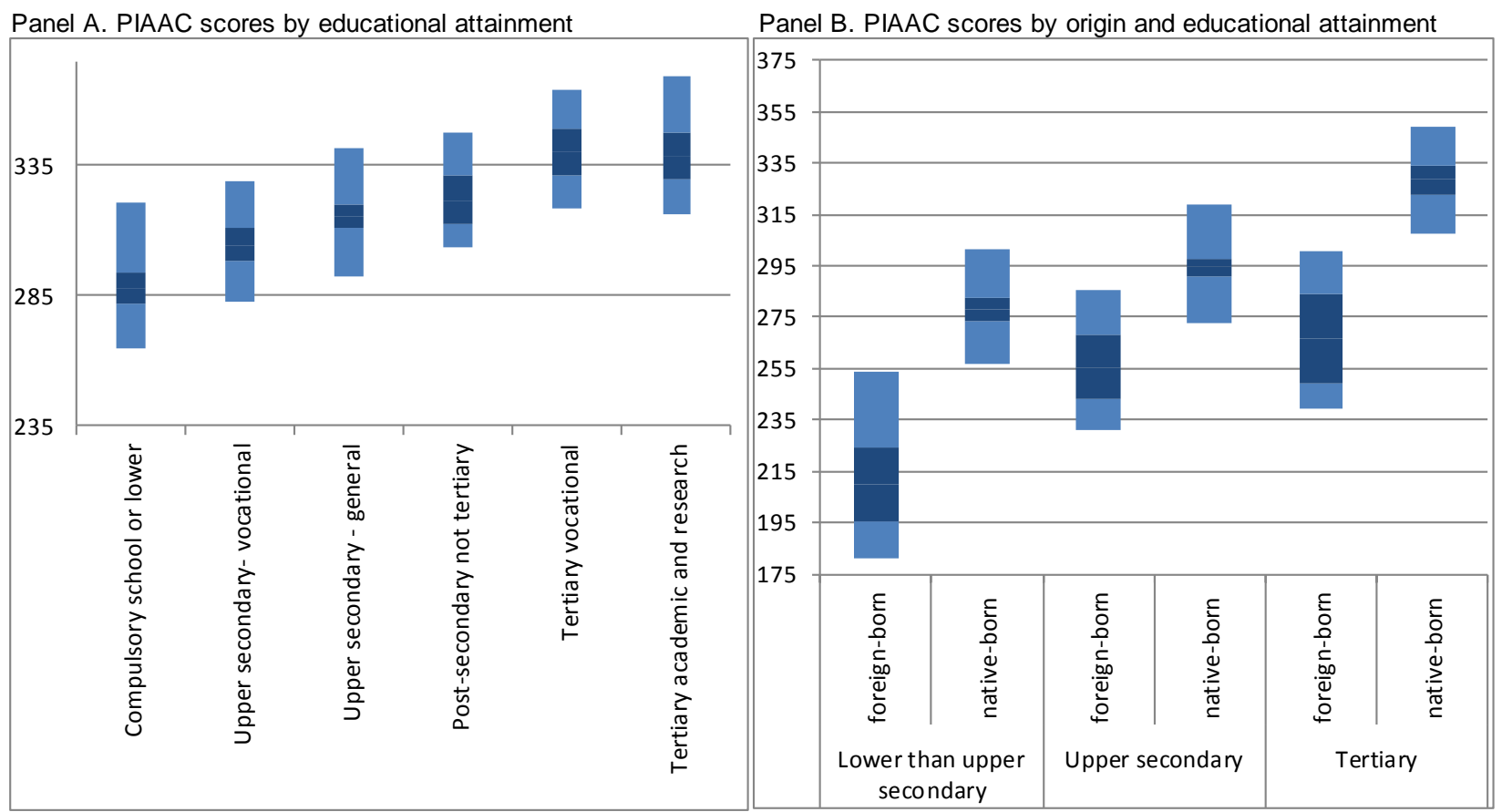

1. The graphs show the range of literacy proficiency between the 25th (lower end) and the 75th (upper end) percentile by educational attainment for young adults in Sweden aged 16 to 29. The mean score and its confidence interval at $95 \%$ are in dark blue in the middle. Estimates are not adjusted for other background variables. Confidence intervals for the foreign-born young adults (Panel $B$ ) are quite large because of small sample size.

Source: Survey of Adult Skills (2012).

\section{Box 1. Proficiency levels in literacy in the PIAAC Survey}

PIAAC measures three cognitive skills, namely literacy, numeracy and problem solving in technology-rich environments. Literacy proficiency is measured in PIAAC in score points. Score points are divided in a 6 level scale ranging from "Below Level 1" to "Level 5 and above".

The OECD Skills Outlook defines the levels as follows:

\section{Proficiency at Level 5 (scores equal to or higher than 376 points)}

Level 5 is the highest proficiency level on the literacy scale. Adults reaching this level can perform tasks that involve searching for and integrating information across multiple, dense texts; construct syntheses of similar texts and contrast ideas or points of view, or evaluate evidence and arguments. They can apply and evaluate logical and conceptual models, and evaluate the reliability of sources and select key information. They are aware of subtle, rhetorical cues and are able to make high-level inferences or use specialised background knowledge.

\section{Proficiency at Level 4 (scores from 326 points to less than 376 points)}

At Level 4, adults can perform multiple-step operations to integrate, interpret, or synthesise information from complex or lengthy continuous, non-continuous, mixed, or multiple-type texts that involve conditional and/or competing information. They can make complex inferences and appropriately apply background knowledge as well as interpret or evaluate subtle truth claims or arguments. 
Proficiency at Level 3 (scores from 276 points to less than 326 points)

Adults performing at Level 3 can understand and respond appropriately to dense or lengthy texts, including continuous, non-continuous, mixed, or multiple pages. They understand text structures and rhetorical devices and can identify, interpret, or evaluate one or more pieces of information and make appropriate inferences. They can also perform multistep operations and select relevant data from competing information in order to identify and formulate responses.

Proficiency at Level 2 (scores from 226 points to less than 276 points)

At Level 2, adults can integrate two or more pieces of information based on criteria, compare and contrast or reason about information and make low-level inferences. They can navigate within digital texts to access and identify information from various parts of a document.

Proficiency at Level 1 (scores from 176 points to less than 226 points)

At Level 1, adults can read relatively short digital or print continuous, non-continuous, or mixed texts to locate a single piece of information, which is identical to or synonymous with the information given in the question or directive. These texts contain little competing information. Adults performing at this level can complete simple forms, understand basic vocabulary, determine the meaning of sentences, and read continuous texts with a degree of fluency.

\section{Proficiency below Level 1 (scores below 176 points)}

Individuals at this level can at max read brief texts on familiar topics and locate a single piece of specific information identical in form to information in the question or directive. They are not required to understand the structure of sentences or paragraphs and only basic vocabulary knowledge is required. Tasks below Level 1 do not make use of any features specific to digital texts.

Source: OECD (2013a), OECD Skills Outlook 2013.

\section{How does the socio-economic background affect literacy scores?}

Socio-economic background may affect the ability to gain employment in different ways. From a policy perspective, it is important to distinguish between the influence of the socio-economic background on building the skills required to gain employment and more direct links between socio-economic background and employment. Hence, the following section investigates the drivers of proficiency in literacy in Sweden, using an ordinary least square (OLS) multivariate regression (Table 1).

Most variables are statistically significant. As expected, the educational attainment is a good predictor for literacy scores. On average, those holding a tertiary degree score 28 points higher than adults holding an upper secondary degree, while those having attained at most lower secondary education score 23 points lower. Average scores in literacy decrease with age, especially for the over-45. Women score on average somewhat lower than men. The family background - measured as parents' educational attainment - has a significant impact on literacy scores. Having neither parent with upper secondary education reduces the mean score in literacy by 9 points, while the opposite effect is found for having at least one parent who has attained tertiary education. Interestingly, being native-born but foreign-language - the first and second language learned at home is not the same as the language of the assessment - does not predict significantly different scores from native-born and native-language adults. This is not the case for foreign-born and foreign-speaker adults who have a score in literacy which is significantly lower than for native-born and native-speaker (- 55 points on average). Furthermore, foreign-born native-speakers (e.g. individuals born abroad but educated in Sweden from a very young age) also score significantly below natives (-11). 
Table 1. Multivariate regression on literacy score

\begin{tabular}{|c|c|}
\hline Female & $\begin{array}{l}-4.80 \\
{[1.52]^{\star *}}\end{array}$ \\
\hline 24 or less & $\begin{array}{l}-6.33 \\
{[2.70]^{\star \star}}\end{array}$ \\
\hline $25-34$ & $\begin{array}{l}0.51 \\
{[2.51]}\end{array}$ \\
\hline $45-54$ & $\begin{array}{l}-6.79 \\
{[2.08]^{\star *}}\end{array}$ \\
\hline More than 55 & $\begin{array}{l}-18.92 \\
{[2.04]^{\star *}}\end{array}$ \\
\hline Max lower secondary education & $\begin{array}{l}-22.75 \\
{[2.45]^{\star *}}\end{array}$ \\
\hline Tertiary education & $\begin{array}{l}27.86 \\
{[1.70]^{\star \star}}\end{array}$ \\
\hline Native-born and foreign-language & $\begin{array}{l}-4.41 \\
{[5.17]}\end{array}$ \\
\hline Foreign-born and native-language & $\begin{array}{l}-11.30 \\
{[4.39]^{* *}}\end{array}$ \\
\hline Foreign-born and foreign-language & $\begin{array}{l}-54.97 \\
{[2.46]^{\star *}}\end{array}$ \\
\hline No parent attained upper secondary education & $\begin{array}{l}-9.10 \\
{[2.19]^{\star *}}\end{array}$ \\
\hline At least one parent attained tertiary education & $\begin{array}{l}5.31 \\
{[1.89]^{\star *}}\end{array}$ \\
\hline Southern Sweden & $\begin{array}{l}-2.64 \\
{[1.74]}\end{array}$ \\
\hline Northern Sweden & $\begin{array}{l}-3.33 \\
{[2.22]}\end{array}$ \\
\hline Constant & $\begin{array}{l}297.38 \\
{[2.60]^{\star \star}}\end{array}$ \\
\hline R2 & 0.39 \\
\hline
\end{tabular}

Note: Standard errors of the coefficients are in brackets, with * and ** indicating significance at the 90 and $95 \%$ level respectively. The reference category is a man with upper secondary education aged between 35 and 44 living in Eastern Sweden. He is native-born and native-speaker and at least one of his parents has attained upper secondary education. Students in full-time education (any age) and young people both in education and employment and aged under 25 are excluded from the regression. Number of observations: 3687.

Source: OECD calculations based on Survey of Adult Skills (2012).

\section{Skills and labour market outcomes}

In Sweden, the mean literacy score for the unemployed and people out of the labour market is 30 points lower than for the employed. This gap is twice as high as on average in countries participating in PIAAC (Figure 4, Panel A). Moreover, when excluding students, the gap between those who are employed and those who are not increases to 45 points. The share of adults with low proficiency (at most level 2 in literacy proficiency) is $42 \%$ of the adult population surveyed, which is smaller than the OECD average (48\%), similar to Norway but higher than Finland (37\%). More than two thirds (71.5\%) of these adults are employed, $7.2 \%$ are unemployed while $21.4 \%$ are out of the labour market. In contrast, for the group with the highest literacy proficiency (Level 5) the share of inactive and unemployed combined is less than 2\%. The share of unemployed adults with at most Level 1 is higher in Sweden (9.2\%) than the OECD average (7.2\%). Similarly, Sweden has a higher percentage of adults scoring below Level 1 who are out of the labour market (40\%) compared to the OECD average (36\%) (Figure 4, Panel B). For higher proficiency levels, unemployment rates are lower in Sweden than the OECD average.

Adults who are in the labour force but unemployed with a PIAAC score of at most Level 2 are predominantly men (58\%). 48\% are native-born and native-speaker and 32\% are between 16 and 34 years old. Adults with at most Level 2 and not in the labour force are mostly women (64\%), 26\% are foreignborn and foreign-speaker. Young people aged between 16 and 34 represent 15\% of those outside the labour market, while adults over 55 represent $62 \%$. 
Figure 4. Literacy proficiency and labour market position

Panel A. Difference in literacy between the employed and the unemployed and inactive ${ }^{1}$

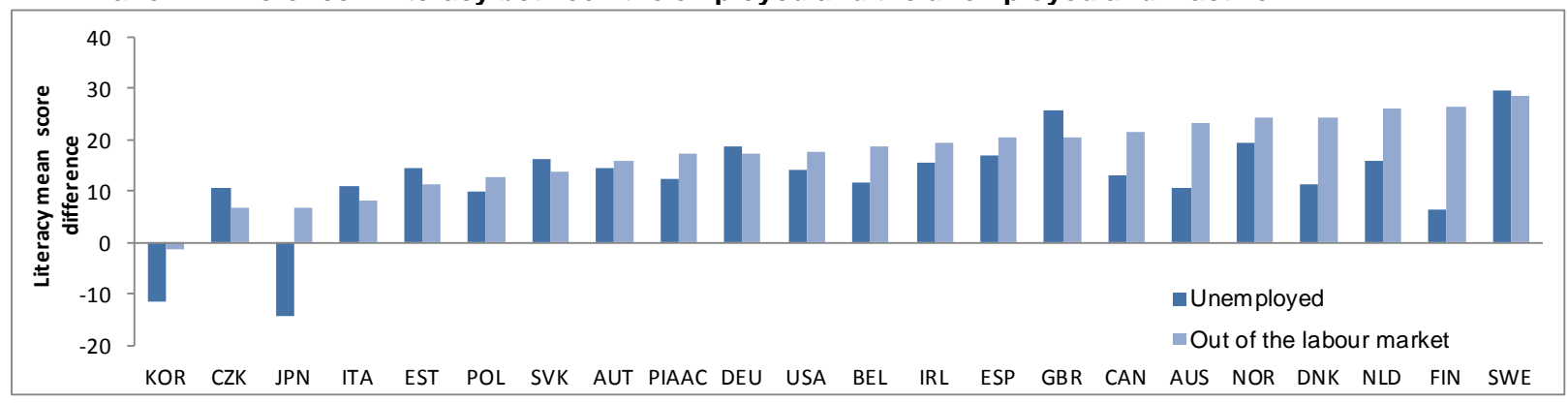

Panel B. Labour market position of adults by proficiency level, Sweden ${ }^{2}$

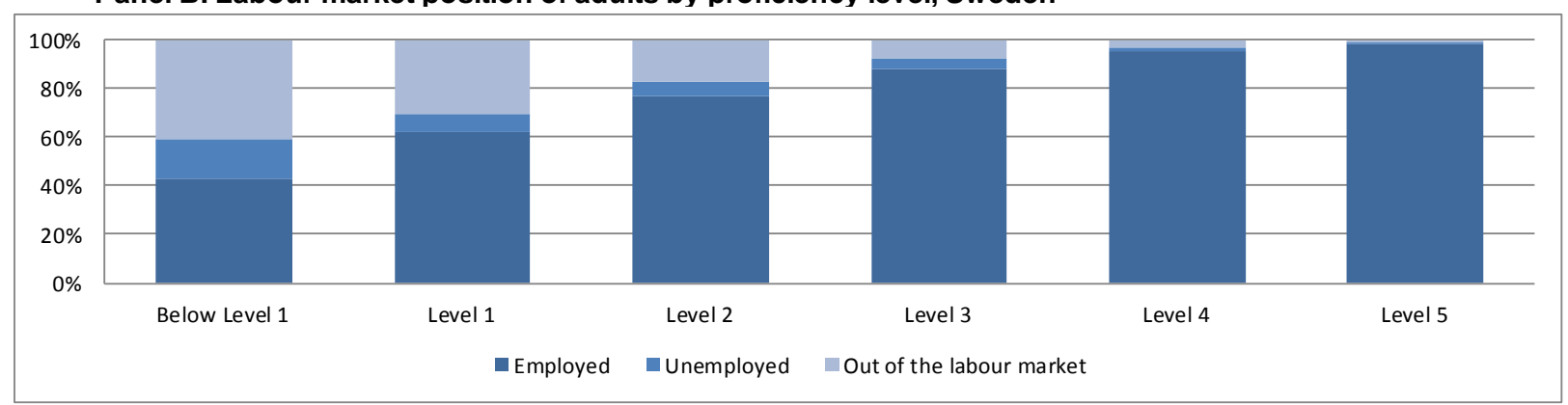

1. "Out of the labour market" includes students.

2. Students are excluded as well as those who are in education and unemployed and aged under 25 .

Source: OECD calculations based on Survey of Adult Skills (2012).

\section{How does literacy affect employment prospects?}

Table 2 (first and second columns) shows the odds ratio of being employed compared to being unemployed or outside the labour market. An individual scoring 50 points higher in literacy proficiency one standard deviation - is estimated to have $85 \%$ higher odds of being employed. ${ }^{2}$ Having a tertiary degree also increases the probability of being employed compared to holding an upper secondary degree. Having a lower educational attainment has a strong negative effect and leads to $51 \%$ lower odds of being in employment. Being a woman is also associated with significantly lower odds of being employed (35\% lower than for a man). Finally, individuals living in the North of the country face reduced odds of employment, controlling for their background.

Surprisingly, being foreign-born and foreign-speaker does not seem to have a significant impact on the likelihood of being employed. However, this is probably due to the fact that background variables are good predictors for literacy scores. To check this, the literacy score is replaced by the residuals of the multivariate regression predicting literacy from the previous section (Table 1). The residuals only account for the part of the variation in literacy which is not explained by socio-economic determinants. ${ }^{3}$ In the regression with the residuals, being foreign-born and foreign-speaker becomes significant and results in

2. As unemployment and inactivity tend to result in skills deterioration, reverse causality may play a role in the relation between skills and employment.

3. The equation from which residuals are calculated is $Y=\beta 0+\beta X+\varepsilon$. where $X$ represents a vector of socioeconomic characteristics which are likely to predict the score on literacy (y) and $\varepsilon$ represents the difference between the observed value of $\mathrm{Y}$ and its predicted value. This residual is then included in the logit regression. 
56\% lower odds of being employed (Table 2, third and fourth column). These results suggest that lower employment prospects for immigrants are mainly due to lower literacy proficiency, since lower average literacy skills among immigrants are reflected in the "foreign-born and foreign-language" category in the second specification. Caution is warranted in interpreting these results, since the quality of employment is not measured, and more immigrants than natives may be over-skilled for their job. Immigrants may also face hurdles gaining employment because of weaknesses in Swedish, even in occupations where the level of fluency is of minor importance.

Table 2. Logit regression on the probability of being employed

\begin{tabular}{|c|c|c|c|c|}
\hline & \multicolumn{2}{|c|}{ Including literacy score } & \multicolumn{2}{|c|}{ Including literacy residuals } \\
\hline & Coefficient & Odds ratio & Coefficient & Odds ratio \\
\hline \multirow[t]{2}{*}{ Literacy } & 0.61 & 1.85 & & \\
\hline & {$[0.07]^{\star \star}$} & & & \\
\hline \multirow[t]{2}{*}{ Literacy residuals } & & & 0.49 & 1.63 \\
\hline & & & {$[0.05]^{\star *}$} & \\
\hline \multirow[t]{2}{*}{ Female } & -0.43 & 0.65 & -0.48 & 0.62 \\
\hline & {$[0.11]^{\star *}$} & & {$[0.11]^{\star *}$} & \\
\hline \multirow[t]{2}{*}{24 or less } & -1.27 & 0.28 & -1.36 & 0.26 \\
\hline & {$[0.23]^{\star \star}$} & & {$[0.23]^{\star *}$} & \\
\hline \multirow[t]{2}{*}{$25-34$} & -0.36 & 0.70 & -0.36 & 0.70 \\
\hline & {$[0.20]^{*}$} & & {$[0.20]^{*}$} & \\
\hline \multirow[t]{2}{*}{$45-54$} & 0.22 & 1.25 & 0.12 & 1.12 \\
\hline & {$[0.21]$} & & {$[0.21]$} & \\
\hline \multirow[t]{2}{*}{ More than 55} & -1.16 & 0.32 & -1.40 & 0.25 \\
\hline & {$[0.17]^{\star \star}$} & & {$[0.17]^{\star *}$} & \\
\hline \multirow[t]{2}{*}{ Max lower secondary education } & -0.71 & 0.49 & -0.99 & 0.37 \\
\hline & {$[0.13]^{\star \star}$} & & {$[0.13]^{\star *}$} & \\
\hline \multirow[t]{2}{*}{ Tertiary education } & 0.37 & 1.44 & 0.71 & 2.03 \\
\hline & {$[0.12]^{\star \star}$} & & {$[0.12]^{\star *}$} & \\
\hline \multirow[t]{2}{*}{ Native-born and foreign-language } & 0.69 & 1.99 & 0.62 & 1.87 \\
\hline & [0.53] & & [0.52] & \\
\hline \multirow[t]{2}{*}{ Foreign-born and native-language } & 0.02 & 1.02 & -0.12 & 0.89 \\
\hline & {$[0.41]$} & & [0.41] & \\
\hline \multirow[t]{2}{*}{ Foreign-born and foreign-language } & -0.14 & 0.87 & -0.82 & 0.44 \\
\hline & [0.15] & & {$[0.13]^{\star *}$} & \\
\hline \multirow[t]{2}{*}{ No parent attained upper secondary education } & -0.05 & 0.95 & -0.16 & 0.85 \\
\hline & [0.18] & & {$[0.18]$} & \\
\hline \multirow[t]{2}{*}{ At least one parent attained tertiary education } & 0.01 & 1.01 & 0.07 & 1.07 \\
\hline & {$[0.17]$} & & {$[0.17]$} & \\
\hline \multirow[t]{2}{*}{ Southern Sweden } & 0.01 & 1.01 & -0.02 & 0.98 \\
\hline & [0.13] & & {$[0.12]$} & \\
\hline \multirow[t]{2}{*}{ Northern Sweden } & -0.23 & 0.80 & -0.28 & 0.76 \\
\hline & {$[0.13]^{*}$} & & {$[0.13]^{\star \star}$} & \\
\hline \multirow[t]{2}{*}{ Constant } & -0.78 & & 2.90 & \\
\hline & {$[0.42]^{*}$} & & {$[0.23]^{\star \star}$} & \\
\hline R2 & 0.18 & & 0.18 & \\
\hline
\end{tabular}

How to read: An odds ratio of 1 represents equal chances of an event occurring for a particular group vis-à-vis the reference group. Coefficients with a value below 1 indicate that there is less chance of an event occurring for a particular group compared to the reference group, and coefficients greater than 1 represent greater chances.

Note: Standard errors of the coefficients are included in brackets, with * and ** indicating significance at the 90 and $95 \%$ level respectively. Literacy and literacy residuals variables are scaled by their respective standard deviations. The reference category is a man aged 35-44, living in Eastern Sweden with upper secondary education and with at least one parent who has attained upper secondary education. He is native-born and native-speaker. Students in full-time education (any age) and young people both in education and employment and aged under 25 are excluded from the regression as education was considered their main activity. Individuals who are inactive represent around $17 \%$ of the whole sample. This is likely to affect the results as maximum-likelihood estimates are dependent on the number of cases in the less frequent of the two categories.

Source: OECD calculations based on Survey of Adult Skills (2012). 


\section{Participation in adult education and training}

Employment rates among those with high literacy proficiency is high, suggesting that the labour market is able to absorb most of the middle and highly skilled, while those with low skills are much more likely to be unemployed or out of the labour market. Furthermore, skills deteriorate when they are not used. The low-skilled are thus in danger of entering a vicious circle where they get further away from the labour market as time passes. Access to adult education and training for the unemployed and the inactive can make a difference.

The employed also need to actively develop their skills. All the more so as $40 \%$ of employees working in high and low-skilled clerical jobs in Sweden experienced substantial restructuring and reorganisation affecting their work environment (OECD, 2013a). Similarly, PIAAC shows that the introduction of new processes or technologies affected $50 \%$ of the high and low-skilled clerical jobs in the three years preceding the survey, the highest share among all participating countries (OECD, 2013a).

Adult education and training helps adults improve their work-related skills or retrain in a specific subject, but it also functions as second chance school for those who dropped out during their studies (Ministry of Education and Research, 2011). Most of the public provision of adult education is focused on upgrading lower skills (basic courses) and allowing the completion of upper secondary education (Box 2). For $25-30 \%$ of the adults without upper secondary education, second chance education plays an important role. $30 \%$ of adults who took part in municipal adult education in 2000 continued to higher education as their main activity later on. Adult education is not only a way of upgrading basic skills in the short run, but also a long-term investment, particularly for young dropouts aged between 18 and 24, among whom almost half went back to higher education after participating in municipal education (Nordlund et al., 2013).

The OECD Skills Outlook highlights that there is a clear relationship between the extent of participation in organised adult learning and the average level of information processing skills in a country (OECD, 2013a). Two thirds of the Swedish adult population participated in formal or non-formal adult education and training (AET) in the 12 months preceding the PIAAC survey. ${ }^{4}$ Formal and non-formal AET includes any type of organised learning activity in which the person has participated, work-related or not, which might be still ongoing and lasted for at least one hour. Half of the adult population participated for job-related reasons and 14\% participated for non-job related reasons. Similar shares taking part in AET are found in the other Nordic countries (OECD, 2013a). The Nordics are the OECD countries involving most their workforce in AET. Sweden has the second largest share of low-proficiency adults (literacy score Below Level 1) taking part in AET in the OECD.

\section{Box 2. Adult education in Sweden}

The State and municipalities are both supposed to provide lifelong learning ranging from standard education to employability courses or on-the-job training. The latest educational reform (2011) stipulates that the provision of courses shall be based on an individual study plan and that validation of competences shall have a prominent role. Like pupils in secondary school and students in higher vocational education, students in adult education receive school guidance. Municipal education and training for adults consists of:

- $\quad$ Municipal adult education (Komvux) leading to the same curriculum and same qualifications as basic adult education (grundläggande vuxenutbildning) and upper secondary adult education (gymnasial vuxenutbildning). Komvux has no programmes, as course provision is individually adapted. In 2012, 116000 persons participated in Komvux education (65\% women).

4. Adult population is defined here as individuals between 16 and 64 excluding youth between 16 and 24 in studies. 
- Special education for adults (Särvux) for adults with special needs.

- $\quad$ Swedish Tuition for Immigrants (SFI) courses are open to immigrants who move to Sweden and are registered in the municipality. Courses should be available at the latest three months after the person registered their move to Sweden. Newly arrived immigrants are entitled to begin SFI classes no later than one year after their registered arrival and for a total duration of maximum two years. Their entitlement to participate in these courses expires after four years.

Publicly-funded education also includes:

- $\quad$ Post-secondary advanced vocational education programmes (yrkeshögskolan). In these courses part of the time is usually spent at a workplace. They are financed by the state and organised by private and public actors and, as from 2012, are offered within the framework of higher vocational education. The programmes last from six months to three years. Courses available are based on labour market analysis from the Swedish National Agency for Higher Vocational Education.

- $\quad$ Supplementary education programmes (kompletterande utbildningar) complement upper secondary education or can be post-secondary education. They are independently set up by private organisers but financially supported by the state. The content of these courses is mainly in specific occupational fields or traditional crafts.

Furthermore, Sweden has a long tradition of liberal adult education (folkbildning) that provides free and voluntary adult education through folk high schools (folkhögskolor) and adult study associations (studieförbund). Currently there are approximately 150 folk high schools in Sweden. The courses last from a few days up to 1-3 years. Some folk high schools provide Swedish tuition for immigrants as well as, among other courses, second-chance education where students can obtain the equivalent qualifications to the compulsory school leaving certificate and the upper secondary school leaving certificate. Liberal adult education receives government grants with the aim to develop activities that contribute to strengthening democracy and people participation. Besides these general guidelines the state does not steer their activities and folk high schools can design their own courses and profiles.

Finally, higher education (universitet och högskolor) plays an important role in lifelong learning in Sweden. Higher education is to a large degree course-based rather than programme-based. This allows higher education institutions to better shape their courses based on local needs, and adults to enrol in specific courses.

Sources: EAEA, 2011; Prime Minister's Office, 2012; Ministry of Education and Research, 2011; Ministry of Education and Research, 2013; Ministry for Higher Vocational Education and Training, 2013.

Across the OECD, the likelihood of participating in adult education and training is significantly higher for those having at least Level 3 literacy proficiency compared to those having literacy scores below Level 1. However, the differences in the probability of participating in AET across literacy level groups are less pronounced in Sweden than in other countries (OECD, 2013a).

A logit regression of the likelihood of participating in adult education and training shows that, as expected, literacy has a strong predictive power (Table 3). A one standard deviation increase in the literacy score (48 score points) increases the odds of participating in adult education and training by $30 \%$. Moreover, being or having been employed in an elementary occupation is associated with $54 \%$ lower odds of participating in training. Women are more likely to take part in adult education and training than men, and higher odds are also found for younger cohorts. Although there is a strong correlation between education and the type of the current or previous job, both predictors are significant. Individuals with lower educational attainments are less likely to have participated in adult education and training in the last 12 months. Being foreign-born does not imply a statistically different probability of attending adult education and training compared to native-born when controlling for background variables. 
Table 3. Logit regression on the likelihood of participating in formal and non-formal adult education

\begin{tabular}{|c|c|c|}
\hline & Coefficient & Odds ratio \\
\hline \multirow[t]{2}{*}{ Literacy } & 0.26 & 1.30 \\
\hline & {$[0.07]^{\star \star}$} & \\
\hline \multirow[t]{2}{*}{ Female } & 0.25 & 1.28 \\
\hline & {$[0.11]^{\star \star}$} & \\
\hline \multirow[t]{2}{*}{24 or less } & 0.48 & 1.62 \\
\hline & {$[0.22]^{\star \star}$} & \\
\hline \multirow[t]{2}{*}{$25-34$} & 0.32 & 1.38 \\
\hline & {$[0.13]^{\star \star}$} & \\
\hline \multirow[t]{2}{*}{$45-54$} & 0.19 & 1.20 \\
\hline & {$[0.14]$} & \\
\hline \multirow[t]{2}{*}{ More than 55} & -0.43 & 0.65 \\
\hline & {$[0.13]^{\star \star}$} & \\
\hline \multirow[t]{2}{*}{ Max lower secondary education } & -0.65 & 0.52 \\
\hline & {$[0.16]^{\star \star}$} & \\
\hline \multirow[t]{2}{*}{ Upper secondary education } & -0.25 & 0.78 \\
\hline & {$[0.1]^{\star \star}$} & \\
\hline \multirow[t]{2}{*}{ Non EU } & 0.19 & 1.20 \\
\hline & {$[0.2]$} & \\
\hline \multirow[t]{2}{*}{ EU } & -0.14 & 0.87 \\
\hline & {$[0.15]$} & \\
\hline \multirow[t]{2}{*}{ Semi-skilled white-collar occupation } & -0.77 & 0.46 \\
\hline & {$[0.12]$} & \\
\hline \multirow[t]{2}{*}{ Semi-skilled and blue-collar occupations } & -0.85 & 0.43 \\
\hline & {$[0.12]$} & \\
\hline \multirow[t]{2}{*}{ Elementary occupation } & -0.98 & 0.38 \\
\hline & {$[0.23]^{\star \star}$} & \\
\hline \multirow[t]{2}{*}{ No parent attained upper secondary education } & -0.10 & 0.90 \\
\hline & {$[0.12]^{\star \star}$} & \\
\hline \multirow[t]{2}{*}{$\begin{array}{l}\text { At least one parent with upper secondary } \\
\text { education }\end{array}$} & -0.11 & 0.89 \\
\hline & {$[0.12]^{\star \star}$} & \\
\hline \multirow[t]{2}{*}{ Southern Sweden } & 0.06 & 1.06 \\
\hline & {$[0.09]$} & \\
\hline \multirow[t]{2}{*}{ Northern Sweden } & -0.09 & 0.91 \\
\hline & [0.12] & \\
\hline \multirow[t]{2}{*}{ Constant } & 0.06 & \\
\hline & {$[0.09]$} & \\
\hline R2_p & -0.09 & \\
\hline
\end{tabular}

How to read: An odds ratio of 1 represents equal chances of an event occurring for a particular group vis-à-vis the reference group. Coefficients with a value below 1 indicate that there is less chance of an event occurring for a particular group compared to the reference group, and coefficients greater than 1 represent greater chances.

Note: Standard errors of the coefficients are included in brackets, with * and ** indicating significance at the 90 and $95 \%$ level respectively. Literacy and literacy residuals variables are scaled by their respective standard deviations. The reference category is a man aged 35-44, born in Sweden and living in Eastern Sweden. Both he and at least one of his parents have attained tertiary education; his current or last job was in a skilled occupation. Adult education and training includes both job-related and unrelated education and training activities. Students in full-time education (any age) and youth both in education and employment and aged under 25 are excluded from the regression.

Source: OECD calculations based on Survey of Adult Skills (2012).

\section{Migrants, literacy and labour market outcomes}

In Sweden PIAAC skills are tested in Swedish, and it is thus not possible to isolate language skills from information processing skills among test-takers. Some other countries offered the test in more than one language. When immigrants score lower than natives, a part of this shortfall is most likely due to language difficulties, especially for newly arrived immigrants. But this is not the full explanation, as 
illustrated by foreign-born native-speaker also doing worse than natives, and similar differences found both in numeracy and in digital problem solving. Lack of proficiency in the language of the country represents a clear obstacle to gaining employment for both the foreign and native-born, although the disadvantage is much greater for the foreign-born (OECD, 2013a).

Sweden has a higher share of migrants in its population than the OECD average. In 2013, 16\% of the Swedish population was born abroad. The immigrant share of the population has been growing steadily over the past decade (OECD, 2013c). Furthermore, labour migration has been largely replaced by humanitarian and family reunion migration during the past decades (OECD, 2012b).

Empirical studies on immigrants' school performance and labour market outcomes suggest that the channels of migration and the country of birth are closely associated with migrants' educational achievements, social network, age and knowledge of the language of the host country or other useful working languages. Humanitarian and asylum seekers often come from non-EU countries and tend to have lower education. Non-EU work migrants are predominantly male and family reunion migrants mostly female (OECD, 2012b). These features have in turn an impact on their labour market outcomes and earnings (Le Grand and Szulkin, 2002;Bevelander and Pendakur, 2014). Moreover, due to institutional factors, the channels of migration affect the composition of the migrant population, as well as skills acquisition and labour market integration, which are two major vectors of broader socio-economic integration. For instance, family migrants and refugees are not selected according to employment-related criteria and their skills might not match local needs (Bevelander and Irastorza, 2014).

PIAAC data and previous analyses (OECD, 2011; Böhlmark, 2008) show that in Sweden the educational attainment of foreign-born adults depends on both the country of birth and the reason for migration. Because it is not possible to break down PIAAC data by migration channel, the data is split into EU and non-EU migrants. ${ }^{5}$ This breakdown broadly matches the distinction between humanitarian and family reunion and free movement migration (Bevelander and Irastorza, 2014). EU and non-EU immigrants have different levels of educational attainment compared to native-born adults. Among the younger cohorts the differences in educational attainment by country of birth are quite pronounced, with EU immigrants being slightly more qualified than natives, while non-EU immigrants show much lower qualifications (Figure 5, Panel A).

Immigrant qualifications are polarised. Among the few work migrants from outside the EU, $80 \%$ of those registered as residents in 2009 had a tertiary degree. Within the much more numerous group of nonEU migrants with permanent residency for asylum reasons, more than $40 \%$ had not completed upper secondary education (OECD, 2011). The gap in literacy proficiency between native and foreign-born adults (both EU and non-EU) is considerably higher in Sweden than in most other OECD countries, partly because the mean scores of natives are relatively high. For all age levels, foreign-born score lower than natives in literacy, numeracy and problem solving in technology-rich environments. Differences between native and foreign-born in both literacy and numeracy are high, at respectively 54 and 56 points. For literacy, this gap is the highest in the OECD, which shows an average of 29 points difference (Figure 5, Panel B).

Educational attainment is a poorer predictor of literacy proficiency among immigrants than among natives. At any educational attainment level, non-EU foreign-born adults have a distribution of proficiency in literacy that is skewed towards the lower levels, compared to natives. EU-foreign born adults have an intermediate position between the native and non-EU born adults (Figure 5, Panel C). This does not only reflect language difficulties, as foreign-born native-speaker also score lower than the native-born nativespeaker.

5. Norway is included in the EU category. 
Figure 5. Literacy proficiency by educational attainment and region of birth

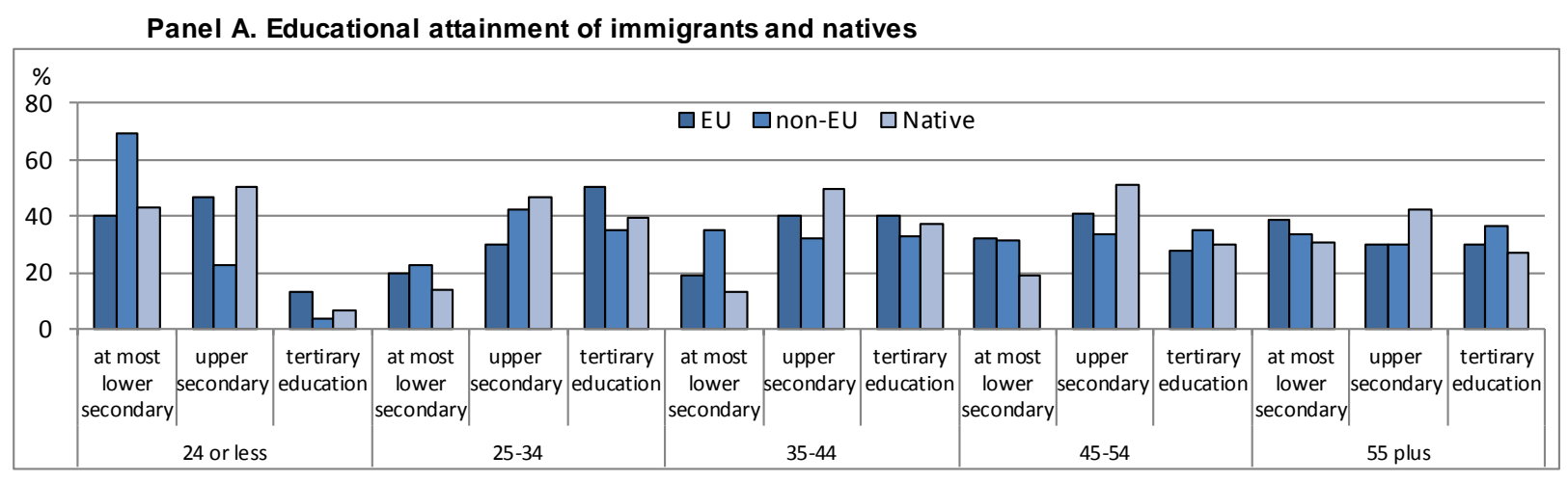

Panel B. Proficiency gap between immigrants and natives
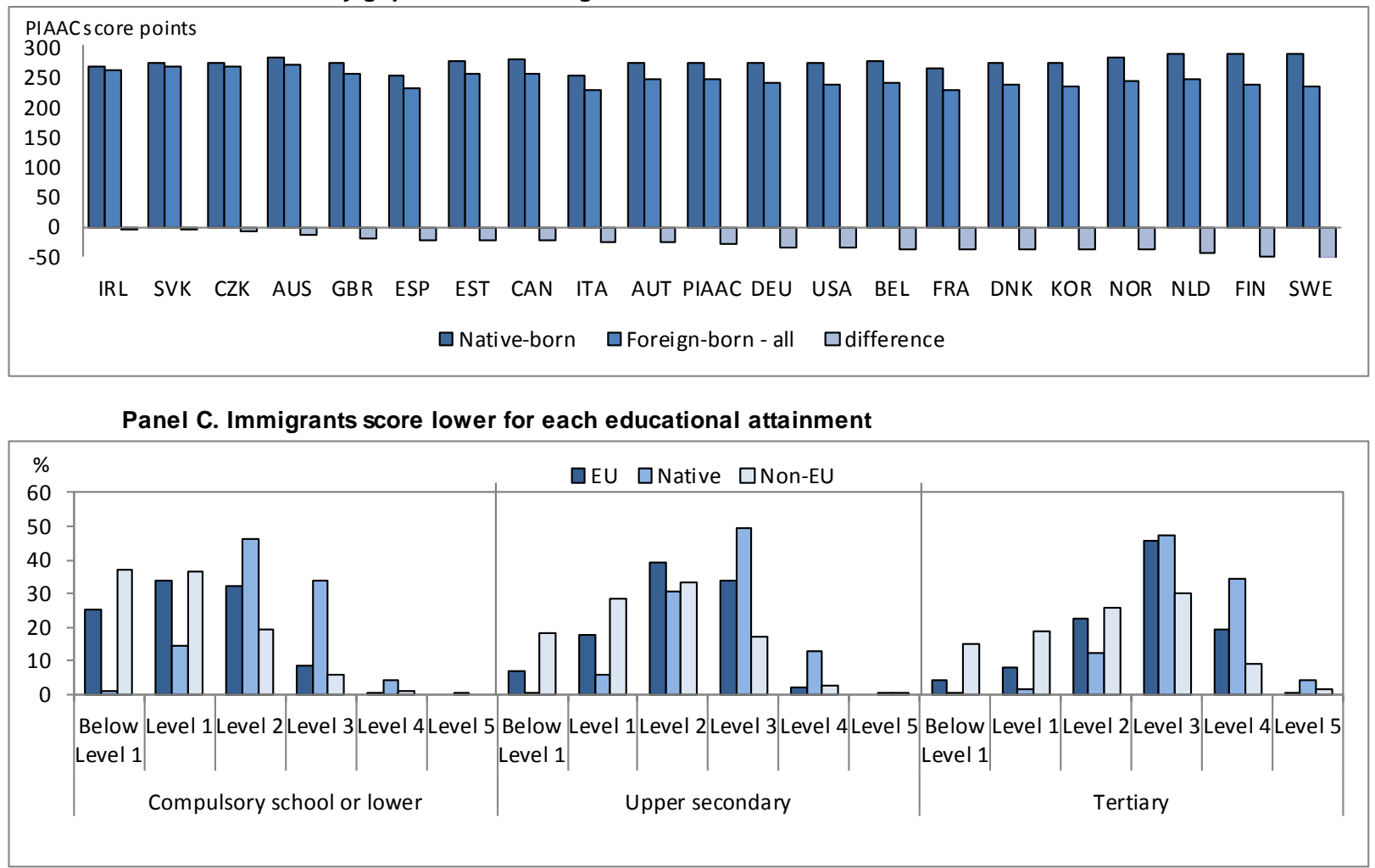

Source: Survey of Adult Skills (2012).

\section{Skills improve markedly with the time spent in the country}

Although not being a longitudinal survey PIAAC data provide a time perspective, since it contains information about the time spent in the host country since immigration. The time dimension is an important factor for explaining school performance and labour market integration of the foreign-born. Migration at an early age increases the likelihood of acquisition of qualifications recognised in the host countries (Böhlmark, 2008). Furthermore, the longer foreign-born adults stay in the country, the more likely they are to acquire host-country language skills. All immigrant groups do worse than natives both before and after five years, but immigrants who have lived for at least five years in Sweden score significantly higher on 
literacy than recent immigrants, and those from the European Union generally do better than those from outside the European Union both before and after five years in Sweden (Figure 6).

Figure 6. Literacy proficiency scores

By region and length of stay in Sweden

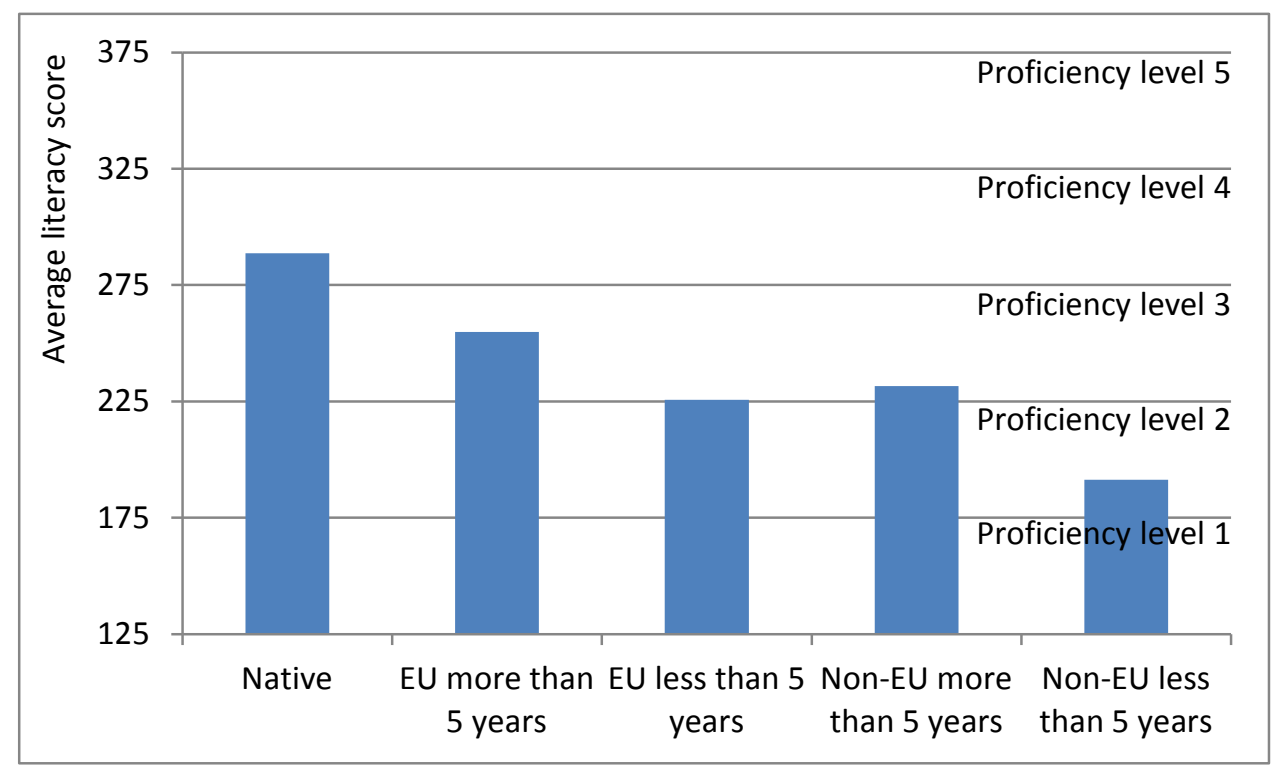

Source: Survey of Adult Skills (2012).

In the PIAAC database, the share of foreign-born adults in Sweden is $17 \%$, which is higher than for other Nordic countries. In terms of length of stay, Finland and Sweden have a similar distribution of foreign-born by time spent in the country, with the newly-arrived (less than five years) representing around $22 \%$ of the foreign-born population. Norway and Denmark show higher percentages of newly-arrived immigrants (respectively $26 \%$ and 32\%).

Foreign-born adults who have spent less than five years in Finland and Sweden have the lowest levels of literacy (respectively 172 and 202 points) of similar groups in OECD countries (on average 231 points). In both countries, the share of humanitarian and family migrants, who have on average lower skill levels, represented at least half of the foreign-born population with permanent residence in 2011 (OECD, 2013c). Although the literacy proficiency of newly arrived immigrants is low, the mean score level of foreign-born adults who have lived more than five years in the host country is higher than the OECD average for Finland and only slightly lower than the average for Sweden. This improvement can be due to several factors. Access to language courses and to adult education more generally are important in this respect.

\section{How does immigrants' socio-economic background affect their literacy scores?}

Previous regressions showed that being foreign-born has a strong predictive power for the score on literacy proficiency in Sweden. However, literacy scores also vary among immigrants, making it interesting to try to identify the variables that are the most likely to predict a high or lower score in PIAAC for the foreign-born. Separate OLS regressions are carried out with native language and region of origin, since these categories overlap. 
ECO/WKP(2015)51

Table 4. Multivariate regressions on literacy proficiency among foreign-born adults

\begin{tabular}{|c|c|c|c|}
\hline & By language & By region & By region and occupation \\
\hline \multirow[t]{2}{*}{ Female } & -7.40 & -3.99 & -3.13 \\
\hline & {$[4.62]$} & {$[4.58]$} & {$[5.75]$} \\
\hline \multirow[t]{2}{*}{ Max lower secondary education } & -32.11 & -30.30 & -26.38 \\
\hline & {$[7.62]^{\star \star}$} & {$[7.45]^{\star \star}$} & {$[8.41]^{\star \star}$} \\
\hline \multirow[t]{2}{*}{ Tertiary education } & 28.54 & 24.97 & 15.00 \\
\hline & {$[5.30]^{\star \star}$} & {$[4.88]^{\star \star}$} & {$[5.45]^{\star \star}$} \\
\hline \multirow[t]{2}{*}{ Southern Sweden } & -3.83 & 0.34 & 5.39 \\
\hline & {$[5.91]$} & {$[5.43]$} & {$[5.48]$} \\
\hline \multirow[t]{2}{*}{ Northern Sweden } & 11.75 & 1.89 & 2.36 \\
\hline & [8.09] & {$[7.84]$} & {$[8.64]$} \\
\hline \multirow[t]{2}{*}{24 or less } & 4.81 & 12.07 & 19.00 \\
\hline & [11.44] & {$[12.6]$} & [12.75] \\
\hline \multirow[t]{2}{*}{$25-34$} & -1.13 & 3.12 & 9.10 \\
\hline & {$[6.85]$} & [7.20] & [7.64] \\
\hline \multirow[t]{2}{*}{$45-54$} & -7.69 & -5.36 & 0.52 \\
\hline & {$[6.86]$} & {$[6.75]$} & {$[6.70]$} \\
\hline \multirow[t]{2}{*}{ More than 55} & -14.59 & -21.12 & -15.15 \\
\hline & {$[6.59]^{\star \star}$} & {$[6.03]^{\star \star}$} & {$[6.88]^{\star \star}$} \\
\hline \multirow[t]{2}{*}{ No parent attained upper secondary education } & -11.84 & -12.34 & -12.12 \\
\hline & {$[7.18]^{\star}$} & {$[7.49]^{*}$} & {$[6.86]^{*}$} \\
\hline \multirow[t]{2}{*}{ At least one parent attained tertiary education } & 10.79 & 12.53 & 11.47 \\
\hline & {$[6.83]$} & {$[6.97]^{\star}$} & {$[6.27]^{*}$} \\
\hline \multirow[t]{2}{*}{ Immigrated less than five years ago } & -28.49 & -29.85 & -29.58 \\
\hline & {$[7.31]^{\star \star}$} & {$[7.09]^{\star *}$} & {$[6.96]^{\star \star}$} \\
\hline \multirow[t]{2}{*}{ Arabic languages } & -38.89 & & \\
\hline & {$[7.24]^{\star \star}$} & & \\
\hline \multirow[t]{2}{*}{ Asian languages } & -31.91 & & \\
\hline & {$[7.33]^{\star \star}$} & & \\
\hline \multirow[t]{2}{*}{ African languages } & -30.65 & & \\
\hline & {$[15.52]^{\star \star}$} & & \\
\hline \multirow[t]{2}{*}{ Arab countries } & & -67.79 & -67.35 \\
\hline & & {$[8.63]^{\star *}$} & {$[8.35]^{\star *}$} \\
\hline \multirow[t]{2}{*}{ Asian countries } & & -51.88 & -48.00 \\
\hline & & {$[8.31]^{\star \star}$} & {$[9.00]^{\star \star}$} \\
\hline \multirow[t]{2}{*}{ Latin America and the Caribbean } & & -28.30 & -25.93 \\
\hline & & {$[9.56]^{\star \star}$} & {$[9.79]^{\star \star}$} \\
\hline \multirow[t]{2}{*}{ Sub-Saharan Africa } & & -54.65 & -47.79 \\
\hline & & {$[14.16]^{\star \star}$} & {$[15.28]^{\star \star}$} \\
\hline \multirow[t]{2}{*}{ Central and Eastern Europe } & & -42.12 & -40.26 \\
\hline & & {$[6.70]^{\star \star}$} & {$[6.92]^{\star \star}$} \\
\hline \multirow[t]{2}{*}{ Skilled occupation } & & & 12.08 \\
\hline & & & [7.64] \\
\hline \multirow[t]{2}{*}{ Semi-skilled blue collar occupation } & & & -15.84 \\
\hline & & & {$[7.72]^{\star \star}$} \\
\hline Elementary occupation & & & -17.92 \\
\hline & & & {$[10.12]^{*}$} \\
\hline Constant & 262.13 & 284.62 & 283.47 \\
\hline & {$[7.78]^{\star \star}$} & {$[9.26]^{\star \star}$} & {$[9.21]^{\star \star}$} \\
\hline R2 & 0.39 & 0.44 & 0.46 \\
\hline
\end{tabular}

Note: Standard errors of the coefficients are included in brackets, with * and ** indicating significance at the 90 and $95 \%$ level respectively. The reference category is a man with upper secondary education, living in Eastern Sweden. He is between 35 and 44 years old, and his current or last occupation was semi-skilled white-collar. He speaks a European language in the first regression, and comes from Europe, the United States or an advanced Pacific economy in the second and third. One of his parents has attained at least upper secondary education and he has been living in the country for more than five years. Students in full-time education (any age) and youth both in education and employment and aged under 25 are excluded from the regression.

Small sample sizes for non-students younger than 25, African countries and African languages may affect the results for these groups. The first two regressions are run for 515 observations, all of them foreign-born and foreign-speaker, while the third regression is run for 447 observations as 68 observations lack an occupational category. The European language category includes: Bosnian, Creoles French-based, Creoles Portuguese-based, Danish, German, Greek, English, Estonian, Finnish, French, Hebrew, Croatian, Hungarian, Icelandic, Italian, Latvian, Lithuanian, Dutch, Norwegian, Polish, Portuguese, Romanian, Romany, Russian, Spanish Albanian, Serbian, Tatar, Turkish, Ukrainian.

Arab countries include: Algeria, Occupied Palestinian Territory, Iraq, Jordan, Kuwait, Lebanon, Morocco, Syrian Arab Republic, Tunisia, Egypt.

Asian countries include: Afghanistan, Bangladesh, Sri Lanka, China, Georgia, India, Indonesia, Iran, Kazakhstan, Kyrgyzstan, Pakistan, Philippines, Viet Nam and Thailand.

Central Eastern European countries include: Bosnia and Herzegovina, Bulgaria, Belarus, Croatia, Estonia, Hungary, Latvia, Lithuania, Republic of Moldavia, Montenegro, Poland, Romania, Russian Federation, Serbia, Turkey, Ukraine, the former Yugoslav Republic of Macedonia.

Latin American countries include: Argentina, Bolivia, Brazil, Chile, Colombia, Cuba, Dominican Republic, Ecuador, Mexico, Peru, Uruguay, Venezuela.

African countries include: Burundi, Cameroon, Cape Verde, Ethiopia, Eritrea, Liberia, Mauritius, Rwanda, Somalia, Togo, Zambia.

Source: OECD calculations based on Survey of Adult Skills (2012). 
The regression including language explains almost 39\% of the variance in literacy among foreignborn adults. Results show that there are no gender differences for literacy proficiency among immigrants when controlling for other relevant factors. Educational attainment, as expected, has strong predictive power. Migrants with tertiary education score 29 points higher than those with upper secondary education, while those with below upper secondary education score 32 points lower. Foreign-born adults with a nonEuropean native language show lower scores in literacy proficiency. The education level of the parents has a statistically significant negative impact on literacy scores when neither parent has attained upper secondary education. Moreover, the variable indicating the time spent in Sweden clearly indicates that the longer people stay, the more they acquire literacy competences in Swedish, which is likely to lead to easier social and economic integration ${ }^{6}$ (Table 4 , first column).

The regression including region of origin explains $44 \%$ of the variance in literacy among foreign-born adults and gives similar results. While Latin-American adults were included in the European language speaker categories, they are treated as a different group in this analysis. Again, time spent in the country and educational attainment predict higher scores among the foreign-born. Coming from outside Western Europe, Northern America and advanced Pacific countries is associated with lower scores in literacy (Table 4, second column).

Including current or previous occupations in the regression, shows that there is no significant difference in literacy between skilled and white-collar semi-skilled professions. In contrast, the gap between white-collar and blue-collar and elementary professions is sizeable. The impact of occupation in explaining literacy is strong even as educational level is controlled for, underlining the importance of matching immigrants with jobs according to their skills to avoid skills deterioration (Table 4, third column).

\section{How does literacy affect immigrants' employment prospects?}

The results of the regressions above confirm that native language and time spent in the country influence the level of proficiency acquired. Similarly, the region of origin is a good predictor for literacy proficiency. These differences are also expected to influence the likelihood of being employed, not only because literacy plays an important role in accessing the labour market but also because immigrants coming from the same region are likely to have similar reasons for migrating, and these reasons probably have an impact on the likelihood of being employed. This impact is explored in two logit regressions on immigrants' odds of being employed. The same background variables as above are included in both regressions. The literacy score is included as explanatory variable in the first regression, and residuals from the second regression in Table 4 are included in the second, to isolate the variation in literacy proficiency that is not explained by the background variables.

6. This result is not driven by the changing composition of immigrants over time, as this is controlled for by including language (country) of origin. Consistency checks, keeping the origin variables while excluding the time spent in Sweden and vice versa do not materially change the size or significance of the coefficients, except for living in Northern Sweden, which becomes insignificant in both of the alternative specifications, indicating a composition effect in this region, as further discussed below. 
Table 5. Logit regression on the probability of being employed for foreign-born adults

\begin{tabular}{|c|c|c|c|c|}
\hline & \multicolumn{2}{|c|}{ Including literacy score } & \multicolumn{2}{|c|}{ Including literacy residuals } \\
\hline & Coefficient & Odds ratio & Coefficient & Odds ratio \\
\hline \multirow[t]{2}{*}{ Literacy } & 0.85 & 2.33 & & \\
\hline & {$[0.23]^{\star \star}$} & & & \\
\hline \multirow[t]{2}{*}{ Literacy residuals } & & & 0.67 & 1.96 \\
\hline & & & {$[0.15]^{\star *}$} & \\
\hline \multirow[t]{2}{*}{ Female } & -0.94 & 0.39 & -1.00 & 0.37 \\
\hline & {$[0.32]^{\star *}$} & & {$[0.32]^{\star *}$} & \\
\hline \multirow[t]{2}{*}{24 or less } & -2.89 & 0.06 & -2.70 & 0.07 \\
\hline & {$[0.78]^{\star \star}$} & & {$[0.8]^{\star \star}$} & \\
\hline \multirow[t]{2}{*}{ 25-34 } & -0.50 & 0.61 & -0.46 & 0.63 \\
\hline & {$[0.44]$} & & {$[0.44]$} & \\
\hline \multirow[t]{2}{*}{$45-54$} & 0.06 & 1.06 & -0.02 & 0.98 \\
\hline & {$[0.50]$} & & {$[0.48]$} & \\
\hline \multirow[t]{2}{*}{ More than 55} & -1.56 & 0.21 & -1.84 & 0.16 \\
\hline & {$[0.42]^{\star \star}$} & & {$[0.42]^{\star *}$} & \\
\hline \multirow[t]{2}{*}{ Max lower secondary education } & -1.45 & 0.23 & -1.88 & 0.15 \\
\hline & {$[0.40]^{\star \star}$} & & {$[0.40]^{\star *}$} & \\
\hline \multirow[t]{2}{*}{ Tertiary education } & -0.25 & 0.78 & 0.08 & 1.09 \\
\hline & [0.35] & & [0.36] & \\
\hline \multirow[t]{2}{*}{ Immigrated less than five years ago } & -0.15 & 0.86 & -0.57 & 0.56 \\
\hline & {$[0.48]$} & & {$[0.43]$} & \\
\hline \multirow[t]{2}{*}{ Arab countries } & -0.91 & 0.40 & -1.78 & 0.17 \\
\hline & {$[0.60]$} & & {$[0.54]^{\star *}$} & \\
\hline \multirow[t]{2}{*}{ Asian countries } & -0.63 & 0.53 & -1.28 & 0.28 \\
\hline & [0.58] & & {$[0.54]^{\star *}$} & \\
\hline \multirow[t]{2}{*}{ Latin America and the Caribbean } & -0.75 & 0.47 & -1.08 & 0.34 \\
\hline & [0.71] & & [0.69] & \\
\hline \multirow[t]{2}{*}{ Sub-Saharan Africa } & -0.39 & 0.68 & -1.15 & 0.32 \\
\hline & [0.92] & & {$[0.87]$} & \\
\hline \multirow[t]{2}{*}{ Central and Eastern Europe } & -0.54 & 0.58 & -1.09 & 0.34 \\
\hline & {$[0.50]$} & & {$[0.47]^{\star *}$} & \\
\hline \multirow[t]{2}{*}{ No parent attained upper secondary education } & -0.29 & 0.75 & -0.47 & 0.62 \\
\hline & {$[0.47]$} & & [0.45] & \\
\hline \multirow[t]{2}{*}{ At least one parent attained tertiary education } & -0.17 & 0.84 & -0.01 & 0.99 \\
\hline & {$[0.38]$} & & [0.39] & \\
\hline \multirow[t]{2}{*}{ Southern Sweden } & -0.46 & 0.63 & -0.45 & 0.64 \\
\hline & {$[0.32]$} & & [0.32] & \\
\hline \multirow[t]{2}{*}{ Northern Sweden } & -1.66 & 0.19 & -1.64 & 0.19 \\
\hline & {$[0.53]^{\star \star}$} & & {$[0.53]^{\star *}$} & \\
\hline \multirow[t]{2}{*}{ Constant } & 1.05 & & 4.87 & \\
\hline & {$[1.20]$} & & {$[0.71]^{\star *}$} & \\
\hline R2_p & 0.30 & & 0.31 & \\
\hline
\end{tabular}

How to read: An odds ratio of 1 represents equal chances of an event occurring for a particular group vis-à-vis the reference group Coefficients with a value below 1 indicate that there is less chance of an event occurring for a particular group compared to the reference group, and coefficients greater than 1 represent greater chances.

Note: Standard errors of the coefficients are included in brackets, with * and ** indicating significance at the 90 and $95 \%$ level respectively. Literacy is scaled by its standard deviation. The reference category is a man with upper secondary education, living in Eastern Sweden. He is between 35 and 44 years old and at least one of his parents has attained upper secondary education, and he has lived in Sweden for more than five years. He comes from Western Europe, North America or an advanced Pacific economy. Students in full-time education (any age) and youth both in education and employment and aged under 25 are excluded from the regression.

Small sample sizes for non-students younger than 25 and African countries may affect the results for these groups. The regression includes 514 observations, all of them corresponding to foreign-born and foreign-speaker.

Source: OECD calculations based on Survey of Adult Skills (2012). 
In the first regression (Table 5, first column), a change of one standard deviation (63 points) in literacy proficiency leads to $133 \%$ higher odds of being employed. ${ }^{7}$ The impact of literacy residuals is somewhat lower, but still sizeable (Table 5, second column). Even though gender did not explain literacy scores, it has a strong predictive power on employment in both specifications. Foreign-born women have more than $60 \%$ lower odds of being employed than men. Age matters in both specifications, with both younger and older cohorts less likely to be employed. Furthermore, individuals without upper secondary education face much lower odds of employment than those with an upper secondary diploma, while a tertiary degree does not make a significant difference. The labour market performance of immigrants varies with their region of origin, but this effect seems to be caused mainly by differences in literacy proficiency. As discussed earlier in this paper, this result does not exclude that different groups of immigrants face discrimination to a varying extent, as the type of employment and the relevance of Swedish language skills in various jobs are not measured in these regressions.

Living in Northern Sweden is associated with lower employment among immigrants with equal skills. The immigrant population of Northern Sweden is quite different from the rest of the country, with almost half of the immigrants coming from Western Europe the United States and advanced Pacific countries, compared to $20 \%$ in the rest of the country, where there is a higher share of immigrants from Central and Eastern Europe and Latin America. The share of Asians, Arabs and Africans is approximately the same across regions. Western Europeans generally have higher literacy proficiency than other groups of immigrants, and in the north of Sweden they are likely to fill high-skill positions, for example in health care and mining. Refugees are placed in municipalities with a surplus of social housing but few jobs adapted to their skills, and are therefore less likely to find work in the north than in the more densely populated areas of the south.

Another counter-intuitive result is that immigrants with a tertiary degree, contrary to natives, do not have significantly higher odds of employment than those with a secondary degree. This may be at least partly due to the relatively low literacy proficiency of foreign-born tertiary graduates compared to natives with similar educational attainment. Furthermore, PIAAC data show that high-proficiency non-EU immigrants (Level 4 and 5) have lower employment rates than non-EU immigrants at proficiency level 3, while employment rates increase with skills for both natives and EU immigrants. Although this is likely partly explained by characteristics included in the regressions above, other obstacles to accessing high level occupations, such as a lack of recognition of foreign diploma or limited social networks may also play a role (OECD, 2014).

7. As unemployment and inactivity tend to result in skills deterioration, reverse causality may play a role in the relation between skills and employment. 


\section{BIBLIOGRAPHY}

Bevelander, P. and R. Pendakur (2014), "The Labour Market Integration of Refugee and Family Reunion Immigrants: A Comparison of Outcomes in Canada and Sweden”, Journal of Ethnic and Migration Studies, Vol. 40, No. 5.

Bevelander, P. and N. Irastorza (2014), "Catching up: Labor Market Outcomes of New Immigrants in Sweden”, Migration Policy Institute and International Labour Office, Washington, DC and Geneva.

Böhlmark, A. (2008), “Age at Immigration and School Performance: A Siblings Analysis Using Swedish Register Data”, Labour Economics, Vol. 15, No. 6.

EAEA (2011), Country Report Sweden, European Association for the Education of Adults, Brussels.

Eurostat (2014), Education and Training statistics, Brussels.

Le Grand, C. and R. Szulkin (2002), "Permanent Disadvantage or Gradual Integration: Explaining the Immigrant-Native Earnings Gap in Sweden”, Labour, Vol. 16, No. 1.

Ministry of Education and Research (2011), OECD - Overcoming School Failure, Country background report Sweden, Stockholm.

Ministry of Education and Research (2013), Adult Education and Training in Sweden, Stockholm.

Ministry for Higher Vocational Education and Training (2013), Skills Beyond School, OECD Review of Postsecondary Vocational Education and Training, Background Report from Sweden, Stockholm.

Nordlund, M., T. Stehlik and M. Strandh (2013), "Investment in Second-Chance Education for Adults and Income Development in Sweden”, Journal of Education and Work, Vol. 26, No. 5.

OECD (2011), Recruiting Immigrant Workers: Sweden 2011, OECD Publishing.

OECD (2012a), Better Skills, Better Jobs, Better Lives: A Strategic Approach to Skills Policies, OECD Publishing.

OECD (2012b), OECD Economic Surveys: Sweden 2012, OECD Publishing.

OECD (2013a), OECD Skills Outlook 2013: First Results from the Survey of Adult Skills, OECD Publishing.

OECD (2013b), PISA 2012 Results: Excellence Through Equity: Giving Every Student the Chance to Succeed (Volume II), PISA, OECD Publishing.

OECD (2013c), International Migration Outlook 2013, OECD Publishing.

OECD (2014), Finding the Way: A Discussion of the Swedish Migrant Integration System, July. http://www.oecd.org/els/mig/swedish-migrant-intergation-system.pdf

OECD (forthcoming), OECD Economic Survey: Sweden 2015, OECD Publishing.

Prime Minister's Office (2012), Sweden's National Reform Programme 2012 - Europe 2020 - EU's Strategy for Smart, Sustainable and Inclusive Growth, Stockholm.

Thunborg, C. and A. Bron (2012), "Higher Education and Lifelong Learning in Sweden”, in Schuetze, H. and M. Slowey (eds.), Global Perspectives on Higher Education and Lifelong Learners, Routledge. 


\section{WORKING PAPERS}

The full series of Economics Department Working Papers can be consulted at www.oecd.org/eco/workingpapers

1232. Skills and inclusive growth in Sweden

(May 2015) by Jon Kristian Pareliussen, Margherita Bussi, Christophe André and Vincent Koen

1231. Incorporating anchored inflation expectations in the Phillips Curve and in the derivation of OECD measures of equilibrium unemployment

(May 2015) by Elena Rusticelli, David Turner and Maria Chiara Cavalleri

1230. Macroeconomic uncertainties, prudent debt targets and fiscal rules,

(July 2015) by Falilou Fall and Jean-Marc Fournier

1229. Limits to government debt sustainability

(July 2015) by Jean-Marc Fournier and Falilou Fall

1228. Government debt indicators: understanding the data

(July 2015) by Debbie Bloch and Falilou Fall

1227. The costs of flexibility-enhancing structural reforms: a literature review

(July 2015) by Tito Boeri, Pierre Cahuc and André Zylberberg

1226. Household finance and income inequality in the euro area

(June 2015) Oliver Denk and Alexandre Cazenave-Lacroutz

1225. Financial sector pay and labour income inequality: evidence from Europe

(June 2015) by Oliver Denk

1224. Finance and income inequality in OECD countries

(June 2015) by Oliver Denk and Boris Cournède

1223. Finance and economic growth in OECD and G20 countries

(June 2015) by Boris Cournède and Oliver Denk

1222. What impedes household investment in energy efficiency and renewable energy?

(May 2015) by Nadia Ameli and Nicola Brandt

1221. Recent trends in productivity in China - shift-share analysis of labour productivity growth and the evolution of the productivity gap

(May 2015) by Margit Molnar and Thomas Chalaux

1220. Assessing China's skills gap and inequalities in education

(May 2015) by Margit Molnar, Boqing Wang and Ruidong Gao

1219. Providing the right skills to all in China - from "made in China" to "created in China"

(May 2015) by Margit Molnar and Vincent Koen

1218. Agricultural reforms and bridging the gap for rural China

(May 2015) by Ben Westmore 
1217. A snapshot of China's service sector

(May 2015) by Margit Molnar and Wei Wang

1216. Does the post-crisis weakness of global trade solely reflect weak demand?

(May 2015) by Patrice Ollivaud and Cyrille Schwellnus

1215. Estonia: raising productivity and benefitting more from openness

(May 2015) by Andreas Kappeler

1214. Estonia: making the most of human capital

(May 2015) by Andrés Fuentes Hutfilter

1213. The Czech labour market: documenting structural change and remaining challenges

(May 2015) by Sónia Araújo and Petr Malecek

1212. Reforming the Slovak public sector

(April 2015) by Lilas Demmou and Robert Price

1211. Spurring growth in lagging regions in the Slovak Republic

Lilas Demmou, Martin Haluš, Gabriel Machlica and Robert Menkyna

1211. Spurring growth in lagging regions in the Slovak Republic

(April 2015) by Lilas Demmou, Gabriel Machlica, Martin Haluš and Robert Menkyna

1210. Skill mismatch and public policy in OECD countries

(April 2015) by Müge Adalet McGowan and Dan Andrews

1209. Labour market mismatch and labour productivity: evidence from PIAAC data

(April 2015) by Müge Adalet McGowan and Dan Andrews

1208. Maintaining an efficient and equitable housing market in Belgium

(April 2015) by Sanne Zwart

1207. Determinants of the low female labour force participation in India

(April 2015) by Piritta Sorsa, Jan Mares, Mathilde Didier, Caio Guimaraes, Marie Rabate,

Gen Tang and Annamaria Tuske

1206. Strengthening skill use and school-to-work transitions in the Czech Republic

(April 2015) by Sónia Araújo and Petr Malecek

1205. Reforming the tax on immovable property: taking care of the unloved

(April 2015) by Hansjörg Blöchliger

1204. Taxation and investment in Colombia

(April 2015) by Sarah Perret and Bert Brys

1203. Efficiency and contestability in the Colombian banking system

(April 2015) by Christian Daude and Julien Pascal 